\title{
Pearls \& Oy-sters: Sturge-Weber Syndrome Unmasked by Traumatic Brain Injury
}

Jeetendra Sah, MD, Clotilde Balucani, MD, PhD, Aaron Abrams, MD, Yoshimi Hisamoto, MD, Geetha Chari, MD, Vinodkumar Velayudhan, DO, and Steven G. Pavlakis, MD

Neurology ${ }^{\circledR}$ 2021;96:e1262-e1265. doi:10.1212/WNL.0000000000011075
Correspondence

Dr. Sah

jeetendra.sah@

downstate.edu

\section{Pearls}

- Minor traumatic brain injury (TBI) can unmask or exacerbate symptoms of Sturge-weber syndrome (SWS).

- SWS can present with exclusive intracranial angiomatosis (type III) without cutaneous or eye findings.

- Preventive measures to avoid TBI are important in patients with SWS.

\section{Oy-sters}

- Neurologic deficit or seizures following minor head injury is not always a manifestation of a postconcussive syndrome, but also may result from underlying structural/vascular lesions.

- Comprehensive diagnostic evaluation should be obtained in patients with progressive neurodeficits after sustaining minor TBI.

- MRI brain without contrast can be unrevealing and contrast-enhanced imaging is required for establishing diagnosis.

A 13-year-old boy presented to the emergency department after sustaining a minor head injury after being pushed and hitting his head on a concrete floor. His Glasgow Coma Scale score was 15 and he was admitted for observation due to difficulty walking. He later developed fluctuating mental status and emesis during the hospital stay. After a few hours, neurologic examination revealed right arm weakness that later progressed to complete right hemiparesis and progressive worsening aphasia. Noncontrast $\mathrm{CT}$ of the head (figure, A) was normal except for an enlarged left internal cerebral vein. Contrast-enhanced MRI of the brain (figure, B) revealed diffuse abnormal leptomeningeal enhancement involving the entire left cerebral hemisphere with an enlarged ipsilateral choroid plexus consistent with the diagnosis of SWS. The patient had no additional clinical features of SWS such as facial angioma, glaucoma, or history of prior neurologic symptoms. He developed refractory status epilepticus (SE) requiring multiple antiseizure medications including levetiracetam, phenytoin, valproate, and midazolam infusion. On day 9 of his hospital stay, the patient developed a complete left oculomotor nerve palsy, which was concerning for raised intracranial pressure and impending uncal herniation. Repeat neuroimaging revealed diffuse left hemispheric cerebral edema (figure, C) with evidence of hyperemia on MRI perfusion, including increased cerebral blood volume and flow (CBV and $\mathrm{CBF}$ ) and decreased mean transit time (MTT) (figure, D-F). He was transferred to the neurocritical care unit for management of refractory SE and worsening brain edema. The patient was not started on aspirin; recent literature suggests a preventive role of aspirin in decreasing the incidence of seizures in SWS. ${ }^{1} \mathrm{He}$ eventually recovered with residual right hemiplegia and was discharged to a rehabilitation center on 2 antiseizure medications (levetiracetam and valproate). 

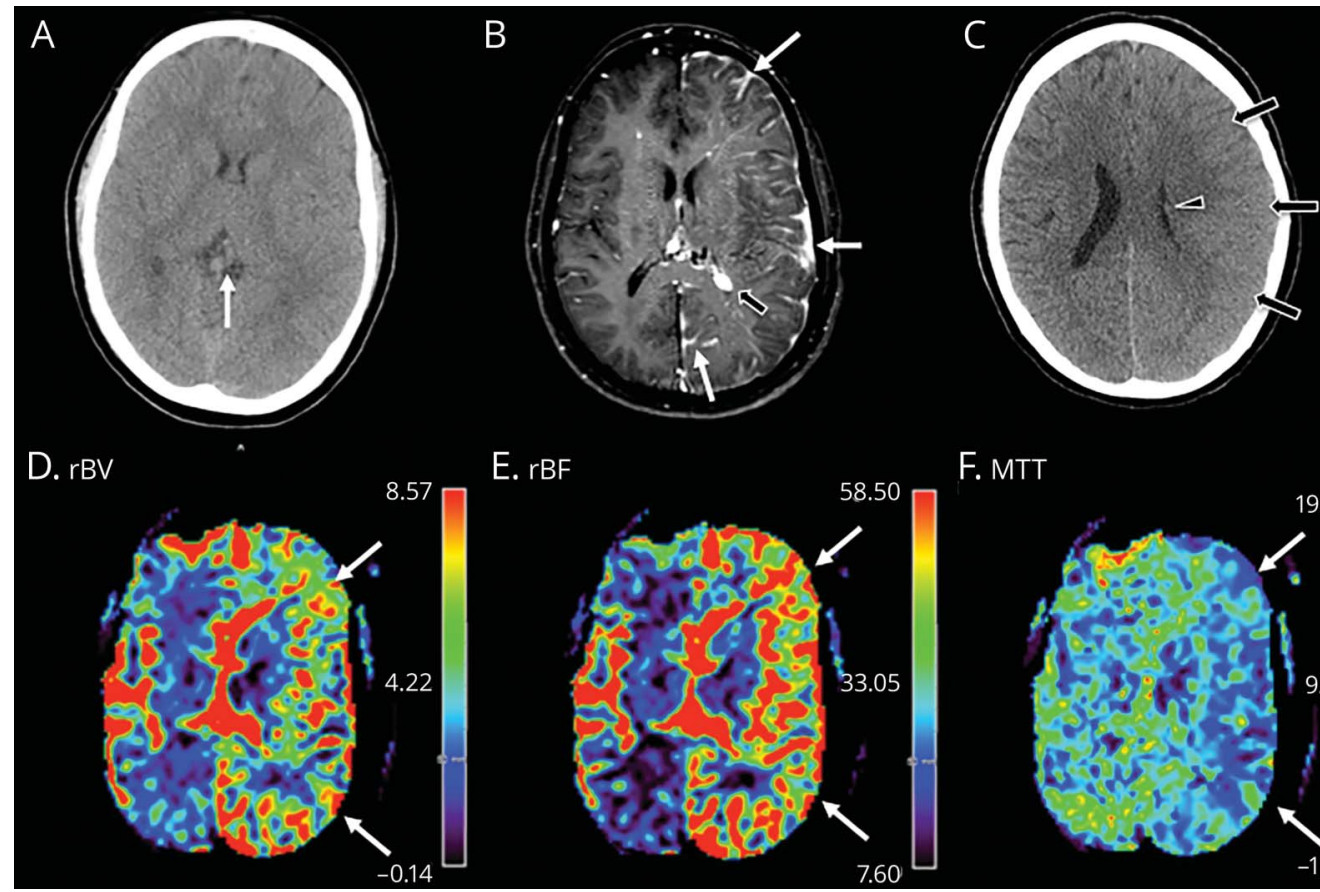

E. rBF
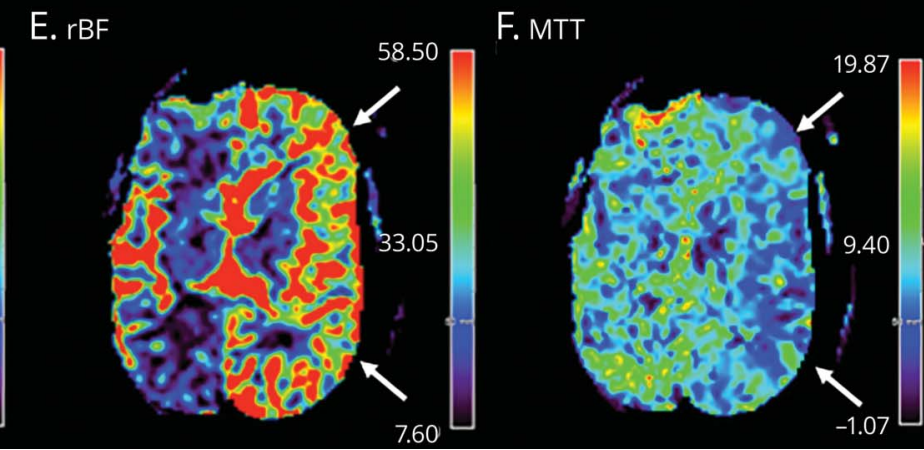

(A) Axial CT demonstrates engorged internal cerebral veins without other abnormal findings. (B) Postcontrast T1-weighted image demonstrates diffusion leptomeningeal enhancement (white arrows) and an enlarged choroid plexus (black arrow) consistent with leptomeningeal angioma and Sturge-Weber syndrome. (C) Axial CT performed after the patient developed status epilepticus and left third cranial nerve palsy demonstrates diffuse left hemispheric edema with sulcal effacement (arrows) and narrowing of the left lateral ventricle (arrowhead). (D-F) Perfusion MRI demonstrates hyperemia in the left cerebral hemisphere (arrows) with elevated relative cerebral blood volume (D) and flow (E) and shortened mean transit time (F).

\section{Discussion}

SWS is a neurocutaneous disorder characterized by a spectrum of clinical and radiologic features including angiomas involving face, choroid vessels of eye, and leptomeninges. SWS is classified into 3 different subtypes based on the distribution of angioma: patients with type I (classic) have both facial and leptomeningeal angiomas and may have glaucoma; patients with type II have only facial angioma and may have glaucoma; patients with type III have isolated leptomeningeal angioma without facial involvement or glaucoma. ${ }^{2}$ Our patient had a rare type III SWS. Similar to previously published cases, TBI worsened the focal neurologic signs and symptoms. ${ }^{3,4}$ Our patient did not have prior neurologic symptoms.

The literature review resulted in a total of 7 cases of SWS with TBI (including ours). The mean age was 9 years and 3 months with 3 male and 4 female patients. In all cases except ours, the diagnosis of SWS was established prior to the head trauma, as facial hemangioma was present in the 6 patients previously reported. A temporal association between the head trauma and the onset of focal weakness or worsening of preexisting residual weakness was noted in all. All patients but ours $(n=6$, $86 \%)$ had history of seizures, focal weakness, or headache. All patients developed focal weakness or worsening of residual weakness after TBI, and 3 patients (42\%) also developed SE along with focal weakness.
The initial presentation of right-sided hemiparesis with fluctuating mental status following TBI raised the suspicion of an ischemic event; however, the diffusion-weighted images (DWI) on MRI brain sequence did not show evidence of acute ischemia. Therefore, it remains unclear whether the hemiparesis was the result of postictal SE or a prolonged hemodynamic impairment without overt ischemia. It is postulated that in SWS abnormal superficial cortical veins with persistent high flow to deep venous system lead to engorgement of deep cortical veins, venous hypertension, vascular stasis, and eventually cerebral atrophy, gliosis, and dystrophic gyral calcification. ${ }^{3}$ The changes in cerebral hemodynamics in SWS and those related to head trauma leading to focal weakness are not well understood.

Several functional hemodynamic studies in the literature related to SWS and TBI depict changes in cerebral hemodynamics in these conditions. A transcranial Doppler (TCD) study involving 8 children with SWS showed reduced mean velocity and increased pulsatility index in the middle cerebral artery (MCA) and posterior cerebral artery (PCA) on the affected side; the difference in flow pattern was more robust in the PCA compared to the $\mathrm{MCA}^{5}$ The authors concluded that this pattern is suggestive of venous stasis resulting in high resistance pattern of blood flow and impaired arterial perfusion.

Classical MRI features of SWS have been well described in the literature and include diffuse leptomeningeal enhancement, 
mostly unilateral, associated with an ipsilateral enlarged choroid plexus and cortical atrophy. Several studies evaluating cerebral MR perfusion (MRP) in SWS have demonstrated abnormalities in the affected areas of the brain with abnormal leptomeningeal enhancement. A series of 6 patients showed cerebral hypoperfusion predominantly due to impaired venous drainage and also found a delayed arterial phase in the most severely affected areas, suggestive of arterial perfusion deficits, which can be used as an imaging marker for severe disease in SWS. ${ }^{6}$

Hyperemia of the affected cerebral hemisphere in SWS has been reported and is believed to represent an early stage of SWS preceding the development of significant brain atrophy. ${ }^{7}$ This pattern appears to have been present in our patient who had not yet developed atrophy, with MRP on day 8 of symptom onset revealing hyperemia with increased left hemispheric CBF, CBV, and decreased TTP and MTT (figure, D-F). Hyperemia in SWS later progresses to the typical pattern of hypoperfusion with atrophy. ${ }^{7}$ Focal cerebral hyperperfusion secondary to focal SE that normalizes after cessation of seizure has been demonstrated. ${ }^{8}$

The hyperemia in our case was likely a result of seizures, early changes of SWS, TBI, or possibly could be an interplay among all these factors. Alteration in cerebral hemodynamics is one of the many pathophysiologic events accompanying the structural and metabolic changes observed after a TBI. Children with mild TBI demonstrate reactivity impairments similar to moderate or severe TBI, with an initial period of increased $\mathrm{CBF}$ followed by a relative decrease, compared to baseline. The evolution of cerebral hemodynamics with TCD was assessed in 70 children between 14 and 19 years of age with concussion and compared to 179 controls. ${ }^{9}$ This study found a significant difference in cerebral hemodynamics in the initial 48 hours after concussion with decreased pulsatility and resistive indices suggestive of impaired cerebral autoregulation and increased velocity. An MRI-based study with susceptibility-weighted imaging and mapping for blood oxygenation quantification showed increased regional $\mathrm{CBF}$ and venous oxygenation in the basal ganglia and frontal and occipital lobes in cases following mild acute TBI compared to controls. ${ }^{10}$ The increased CBF and venous oxygenation may be a mechanism to protect neural tissue in the acute stage of TBI as the greater blood flow exceeds the oxygen demand of brain tissue.

In SWS, there is a compromised cerebrovascular arterial regulation secondary to overcongestion of venous system. Impaired cerebral autoregulation has also been documented in TBI. We postulate that our patient with asymptomatic SWS likely had preexisting abnormal cerebral autoregulation. Minor TBI triggered further cerebral hemodynamic changes, exhausting an already compromised venous system, leading to neuronal dysfunction and consequent clinical manifestation. It is possible that these changes are subtle and can only be captured with functional imaging; despite the finding of right hemiparesis, the MRI brain did not show evidence of overt ischemia on DWI. The exact pathophysiology involved in the manifestation of focal weakness and seizure in SWS related to TBI is not well understood and further observations are needed to confirm that a TBI can exhaust the compromised cerebrovascular autoregulation and alter cerebral perfusion in patients with SWS. Based on the available evidence, head trauma may induce clinical deterioration in SWS. Therefore, we suggest that physicians advise special precautions for these children, including avoiding contact sports.

\section{Study Funding}

No targeted funding reported.

\section{Disclosure}

The authors report no disclosures. Go to Neurology.org/N for full disclosures.

Appendix Authors

\begin{tabular}{|c|c|c|}
\hline Name & Location & Contributions \\
\hline $\begin{array}{l}\text { Jeetendra } \\
\text { Sah, MD }\end{array}$ & $\begin{array}{l}\text { SUNY Downstate Health } \\
\text { Sciences University, Kings } \\
\text { County Hospital Center, } \\
\text { Brooklyn, NY }\end{array}$ & $\begin{array}{l}\text { Described the case, had } \\
\text { major role in literature } \\
\text { review and data analysis, } \\
\text { revised the manuscript for } \\
\text { intellectual content }\end{array}$ \\
\hline $\begin{array}{l}\text { Clotilde } \\
\text { Balucani, } \\
\text { MD, PhD }\end{array}$ & $\begin{array}{l}\text { Johns Hopkins Hospital, } \\
\text { Baltimore, MD }\end{array}$ & $\begin{array}{l}\text { Described the case, had } \\
\text { major role in literature } \\
\text { review, revised the } \\
\text { manuscript for intellectual } \\
\text { content }\end{array}$ \\
\hline $\begin{array}{l}\text { Aaron } \\
\text { Abrams, MD }\end{array}$ & $\begin{array}{l}\text { SUNY Downstate Health } \\
\text { Sciences University, Kings } \\
\text { County Hospital Center, } \\
\text { Brooklyn, NY }\end{array}$ & $\begin{array}{l}\text { Literature review and } \\
\text { revision of manuscript }\end{array}$ \\
\hline $\begin{array}{l}\text { Yoshimi } \\
\text { Hisamoto, } \\
\text { MD }\end{array}$ & $\begin{array}{l}\text { SUNY Downstate Health } \\
\text { Sciences University, Kings } \\
\text { County Hospital Center, } \\
\text { Brooklyn, NY }\end{array}$ & $\begin{array}{l}\text { Literature review, revised } \\
\text { the manuscript for } \\
\text { intellectual content }\end{array}$ \\
\hline $\begin{array}{l}\text { Geetha } \\
\text { Chari, MD }\end{array}$ & $\begin{array}{l}\text { SUNY Downstate Health } \\
\text { Sciences University, Kings } \\
\text { County Hospital Center, } \\
\text { Brooklyn, NY }\end{array}$ & $\begin{array}{l}\text { Literature review, revised } \\
\text { the manuscript for } \\
\text { intellectual content }\end{array}$ \\
\hline $\begin{array}{l}\text { Vinodkumar } \\
\text { Velayudhan, } \\
\text { DO }\end{array}$ & $\begin{array}{l}\text { SUNY Downstate Health } \\
\text { Sciences University, Kings } \\
\text { County Hospital Center, } \\
\text { Brooklyn, NY }\end{array}$ & $\begin{array}{l}\text { Literature review and } \\
\text { selection of images }\end{array}$ \\
\hline $\begin{array}{l}\text { Steven G. } \\
\text { Pavlakis, MD }\end{array}$ & $\begin{array}{l}\text { SUNY Downstate Health } \\
\text { Sciences University, Kings } \\
\text { County Hospital Center, } \\
\text { Brooklyn, NY }\end{array}$ & $\begin{array}{l}\text { Major role in literature } \\
\text { review and data analysis, } \\
\text { revised the manuscript for } \\
\text { intellectual content }\end{array}$ \\
\hline
\end{tabular}

\section{References}

1. Day AM, Hammill AM, Juhász C, et al. Hypothesis: presymptomatic treatment of Sturge-Weber syndrome with aspirin and antiepileptic drugs may delay seizure onset. Pediatr Neurol 2019;90:8-12.

2. Roach ES. Neurocutaneous syndromes. Pediatr Clin North Am 1992;39:591-620.

3. Zolkipli Z, Aylett S, Rankin PM, Neville BGR. Transient exacerbation of hemiplegia following minor head trauma in Sturge-Weber syndrome. Dev Med Child Neurol 2007;49:697-699.

4. Ahmed S, Paul SP. Hemiplegia following mild head injury in a child with Sturge-Weber syndrome: a diagnostic dilemma. J Coll Physicians Surg Pak 2016;26:704-706. 
5. Jordan LC, Wityk RJ, Dowling MM, DeJong MR, Comi AM. Transcranial doppler ultrasound in children with Sturge-Weber syndrome. J Child Neurol 2008;23:137-143.

6. Lin DDM, Barker PB, Hatfield LA, Comi AM. Dynamic MR perfusion and proton MR spectroscopic imaging in Sturge-Weber syndrome: correlation with neurological symptoms. J Magn Reson Imaging 2006;24:274-281.

7. Miao Y, Juhasz $\mathrm{C}, \mathrm{Wu}$ J, et al. Clinical correlates of white matter blood flow perfusion changes in Sturge-Weber syndrome: a dynamic MR Perfusion-weighted imaging study. AJNR Am J Neuroradiol 2011;32:1280-1285.
8. Warach S, Levin JM, Schomer DL, Holman BL, Edelman RR. Hyperperfusion of icta seizures focus demonstrated by MR perfusion imaging. AJNR Am J Neuroradiol 1994; 15:965-968.

9. Thibeault CM, Thorpe S, O'Brien MJ, et al. A cross-sectional study on cerebra hemodynamics after mild traumatic brain injury in a pediatric population. Front Neurol 2018;9:200.

10. Doshi H, Wiseman N, Liu J, et al. Cerebral hemodynamic changes of mild traumatic brain injury at the acute stage. PLoS One 2015;10:e0118061. 


\section{Neurology}

Pearls \& Oy-sters: Sturge-Weber Syndrome Unmasked by Traumatic Brain Injury Jeetendra Sah, Clotilde Balucani, Aaron Abrams, et al.

Neurology 2021;96;e1262-e1265 Published Online before print October 16, 2020

DOI 10.1212/WNL.0000000000011075

This information is current as of October 16, 2020

\section{Updated Information \&} Services

References

Subspecialty Collections

Permissions \& Licensing

Reprints including high resolution figures, can be found at: http://n.neurology.org/content/96/8/e1262.full

This article cites 10 articles, 2 of which you can access for free at: http://n.neurology.org/content/96/8/e1262.full\#ref-list-1

This article, along with others on similar topics, appears in the following collection(s):

Arteriovenous malformation

http://n.neurology.org/cgi/collection/arteriovenous_malformation Brain trauma

http://n.neurology.org/cgi/collection/brain_trauma

Childhood stroke

http://n.neurology.org/cgi/collection/childhood_stroke

Other neurocutaneous disorders

http://n.neurology.org/cgi/collection/other_neurocutaneous_disorders

Partial seizures

http://n.neurology.org/cgi/collection/partial_seizures

Information about reproducing this article in parts (figures,tables) or in its entirety can be found online at:

http://www.neurology.org/about/about_the_journal\#permissions

Information about ordering reprints can be found online:

http://n.neurology.org/subscribers/advertise

Neurology ${ }^{\circledR}$ is the official journal of the American Academy of Neurology. Published continuously since 1951, it is now a weekly with 48 issues per year. Copyright () 2020 American Academy of Neurology. All rights reserved. Print ISSN: 0028-3878. Online ISSN: 1526-632X.

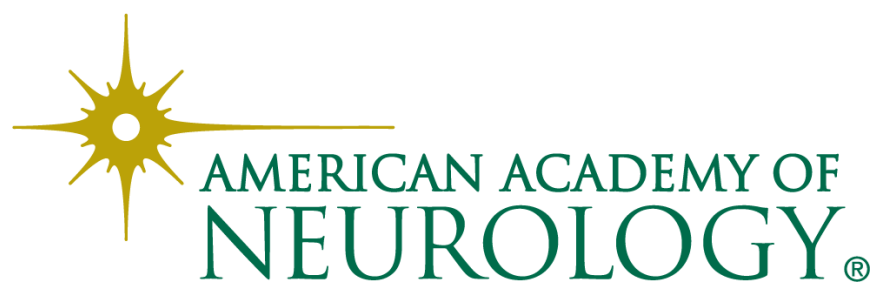

